\title{
Hazards of Bisphenol A on the Thyroid Gland of Adult Male Albino Rats and Possibility of Recovery after its Withdrawal
}

\author{
IBRAHIM H. IBRAHIM, M.D. and MANAL M. MORSY, M.D. \\ The Department of Human Anatomy and Embryology, Faculty of Medicine, Zagazig University, Sharkia, Egypt
}

\begin{abstract}
Background: Bisphenol A (BPA) is a chemical pollutant and one of the endocrinal disrupting factors.

Aim of Study: This study was designed to evaluate the possible changes that may occur in thyroid gland of male adult rats following BPA administration and to access the possibility of the thyroid recovery after stoppage of its administration.
\end{abstract}

Materials and Methods: 36 male adult wistar albino rats were divided into 3 equal groups (control, BPA treated and recovery). For 8 weeks, each animal in the treated group received orally BPA $50 \mathrm{mg} / \mathrm{kg} /$ day, also rats in the recovery group dosed BPA similar to the treated group then held for another 4 weeks without BPA administration. Finally when the experiment was ended, the rats were anesthetized, sacrificed and blood samples were obtained to measure the levels of thyroid hormones. The thyroid gland was processed for histological, histochemical and immunohistochemical $\mathrm{Bcl} 2$ studies. Also, morphometric studies were accessed.

Results: In BPA treated group, there were vacuolated follicular cells, exfoliation of epithelial cells inside the colloid and congested capillaries in the interfollicular spaces. Marked decrease of colloidal PAS reaction and the Bcl2 immunoreaction with increase of the amount of collagen fibers were observed. Also, these results were demonstrated morphometrically. Significant reduction of triiodo-thyronine (T3), thyroxine (T4) and significant increase of thyroid stimulating hormone (TSH) were recorded. In the recovery group, partial improvement of the histological, histochemical, biochemical and immunohistochemical changes caused by BPA was recorded.

Conclusion: Exposure to BPA could result in histological and functional changes of thyroid gland that were incompletely improved after stoppage of BPA administration.

Key Words: Bisphenol A-thyroid gland-Rats - Bcl 2 .

\section{Introduction}

ENDOCRINAL disruptors defined as compounds that unfortunately change the normal function of

Correspondence to: Dr. Ibrahim H. Ibrahim, E-Mail: ebrahimelazonv5555@yahoo.com endocrinal system. These endocrinal disruptors are widely spread chemical pollutants in the surrounding environment $[1,2]$. Also, disruption of the endocrinal system by these compounds has a major effect on the onest of puberty and the age of menarache [3]. The effect of Bisphenol A (BPA) on the thyroid gland is not clear and it has estrogenic effect $[2,4]$. BPA is an organic polymer used in dental materials as well as in production of polycarbonate plastic materials and resins that coat the metal cans and pipes for water supply $[\mathbf{5 , 6 ]}$. Humans are exposed to BPA through consumption of water and food contaminant with it [7-9]. BPA is inhaled with dust from the air or absorped through the skin [10] and was detected in saliva [11]. Thyroid hormones have important biological functions and have vital role in growth and development in early fetal stages especially for the brain $[12,13]$. Some authors postulated that, the environmental chemicals or toxicants change the thyroid hormones secretion or synthesis through their direct effect on thyroid gland or disturbances of the hypothalamic or pituitary gland control [12]. BPA antagonizes triiodothyronine (T3) binding to thyroid hormone receptors and impairs the action of thyroid hormone [2]. The lowest dose of BPA studied for reported effects and risk assessment purposes was $50 \mathrm{mg} / \mathrm{kg} /$ day [14] . Many studies were done for demonstration of testicular and epididymis changes by BPA administration $(50 \mathrm{mg} / \mathrm{kg} /$ day $)$ using oral gavage for 8 weeks [15-16]

The aim of this work was evaluation of the changes that occur in the structure and function of thyroid gland after oral administration of BPA in adult male wistar rats and to evaluate the possibility of recovery after stoppage of BPA administration. 


\section{Materials and Methods}

\section{Animals:}

36 adult male wistar albino rats (Weighted 185$210 \mathrm{gm})$ were obtained from animal house of Zagazig Scientific and Medical Research Center (ZSMRC). This study was done between October 2018 and March 2019, also all animal experiments were approved in agreement with Institutional Animal Care and Use Committee, Zagazig University (ZU-IACUC/3/F/97/2018). The animals were housed in 3 equal groups in separate cages with controlled temperature and 12h. light/12h. dark cycle. Free access to diet and water was allowed for rats. The rats were allowed for adaptation 7 days before the beginning of the study.

\section{Chemicals and experimental BPA solution:}

BPA powder (Alpha Chemika, India, B37880) that was bought from Cairo Chemical Company and dissolved in corn oil to reach concentration $10 \mathrm{mg} / \mathrm{ml}$.

\section{Experimental procedure:}

The animals were divided into 3 groups, (12 rats were present in each group).

The 1 st (control) group: That was subdivided into 2 subgroups (negative and positive control groups, 6 rats each) as follow:

Negative control group: The animals did not receive any treatment.

Positive control group: Each animal received $1 \mathrm{ml}$ corn oil orally as a single dose per day for 8 weeks via gavage.

The ${ }^{2 n d}$ (BPA treated) group: Each rat received $1 \mathrm{ml}$ of BPA solution (BPA $50 \mathrm{mg} / \mathrm{kg} /$ day) $[\mathbf{1 4 , 1 7 ]}$ (single oral dose daily for 8 weeks via gavage).

The 3 rd (recovery) group: Each rat was given a dose as in the 2 nd group exactly then held without administration of BPA for another 4 weeks. At the end of this experimental study, the rats were anesthetized by intraperitoneal injection of thiopental $\mathrm{Na}(50 \mathrm{mg} / \mathrm{Kg})$ and blood samples were obtained by heart puncture then the rats were sacrificed and the thyroid glands were excised and placed in $10 \%$ formalin for histological examination.

\section{Histological study:}

The specimens of thyroid glands were processed then embedded in paraffin and sections (5 m thick) were prepared and stained with the followings:

- Hematoxylin and eosin [18]
- Mallory's trichrome to detect collagen fibers [18].

- Periodic Acid Schiff for detection of mucopolysaccharides [19].

- Immunohistochemistry for antiapoptotic marker (Bcl2 protein) [20] . [Bcl2 (124) is a mouse monoclonal IgG, cat: 226M-95, Cell Marque Corporation, USA) at dilution 1: 300]. Detection of the antibody was performed using avidin biotin peroxidase technique. Light microscopic examination and photography were done for all thyroid stained sections by Leica DM500 photomicroscope (German).

Biochemichal hormonal assay for thyroid function [21]:

The levels of serum T3, thyroxine (T4) and thyroid stimulating hormone (TSH) were measured by Enzyme-Linked Immunosorbent Assay.

\section{Morphometric study:}

The morphometric study was performed using Image J software (Wayne Rasband, National Institute of Mental Health, Bethesda, Maryland, USA). Follicular epithelial height (FEH) and external follicular diameter (EFD) were measured in $\mathrm{H}$ \& E stained thyroid sections, colloid area percentage was measured in PAS stained sections, collagen area percentage was measured in Mallory's trichrome stained sections, while area percentage of $\mathrm{Bcl} 2$ immunoexpression was measured in immune stained sections of thyroid gland. All measurements were performed in 6 non overlapping fields in 6 random sections in 6 different rats in each group at magnification $\mathrm{X} 400$.

\section{Statistical study:}

Statistical analysis was performed using SPSS statistical software, version 19 . The data were presented as arithmetic means \pm standard deviation. Statistical differences between different groups were performed using One-way analysis of variance (ANOVA) followed by Post Hoc test (Least significant difference (LSD)). The statistical significance was considered when. Probability $(\mathrm{P})$ value less than or equal to 0.05 .

\section{Results}

\section{Light microscopic results:}

As comparing the histopathological and the immunohistochemical results in the negative control and positive control groups, the results showed nearly similar findings. So, we used negative control group to be compared with other groups. 


\section{Haematoxylin and eosin $(H \& E)$ staining:}

The thyroid gland in $\mathrm{H} \& \mathrm{E}$ stained sections of the control group consisted of numerous follicles of different sizes. The follicles were filled with acidophilic colloid and lined by simple cubical epithelial cells that had basophilic rounded vesicular nuclei. The colloid showed some peripheral vacuoles. Large pale stained cells named parafollicular cells present adjacent to the follicles of thyroid gland (Fig. 1A).

$\mathrm{H} \& \mathrm{E}$ stained sections from thyroid gland of BPA treated group revealed that thyroid follicles were lined by vacuolated follicular cells with darkly stained nuclei. Also the follicles showed marked colloidal vacuolation. Interfollicular spaces showed congested dilated capillaries (Fig. 1B). Also, diminution of the size of some follicles (micro follicles) were recorded (Fig. 1C). Some follicles in the BPA treated group revealed areas of disturbances of the basal lamina with coalescence of the follicles and exfoliation of the epithelial cells inside the colloid (Fig. 1D).

$\mathrm{H} \& \mathrm{E}$ stained sections from thyroid gland of the recovery group, revealed improvement in most of follicles that regained its normal architecture with disappearance of exfoliation of epithelial cells from their lumina. The follicles were filled with colloid and lined with cubical follicular cells that had vesicular nuclei. However the colloid of some follicles revealed some vacuoles. The blood capillaries still showed some congestion (Fig. 1E).
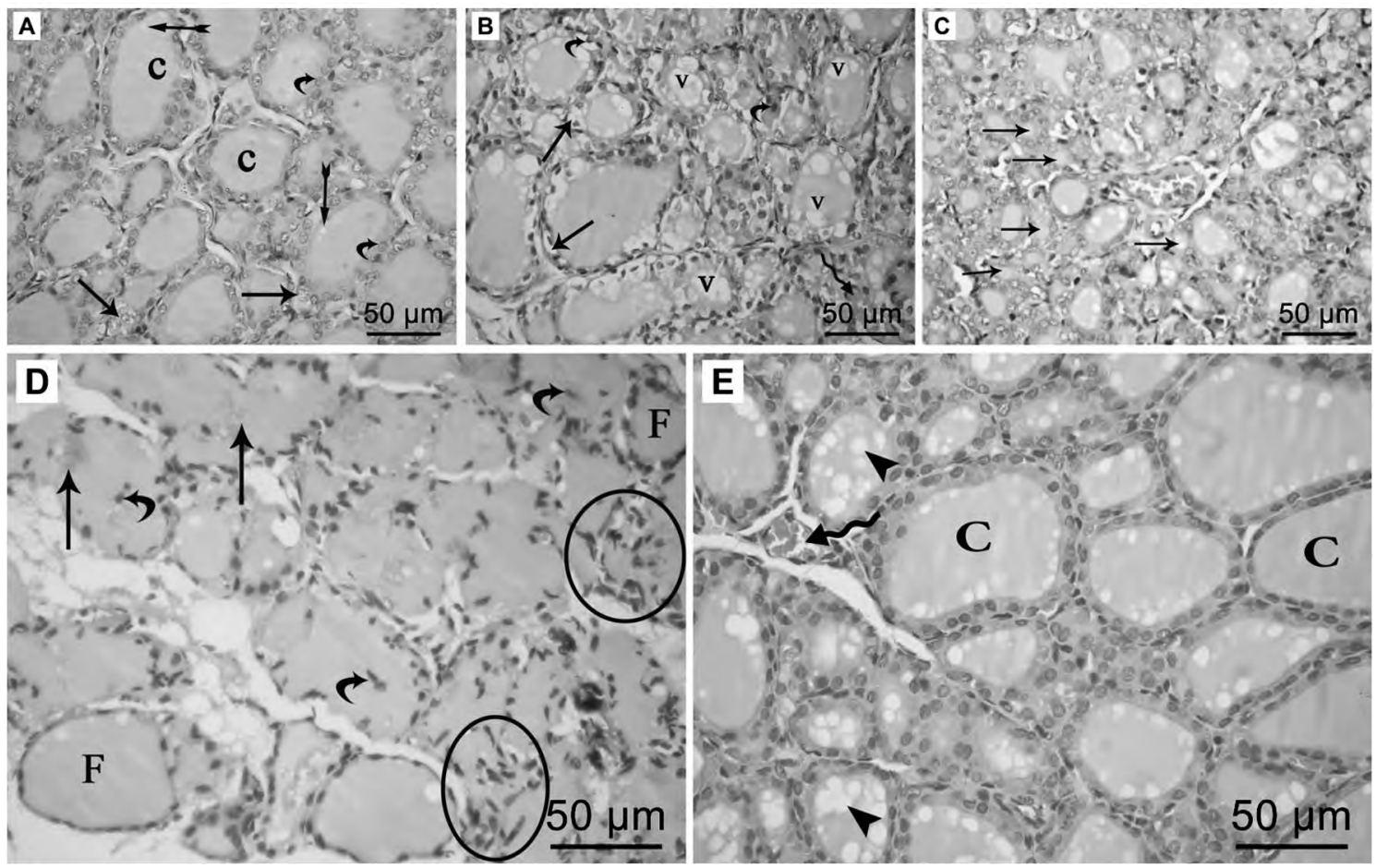

Fig. (1A): A photomicrograph of the thyroid gland in the control group: The thyroid gland showed numerous follicles that were filled with acidophilic colloid (c) that showed peripheral vacuoles in some follicles (tailed arrow). The follicles were lined by simple cubical epithelial cells that had basophilic rounded vesicular nuclei (curved arrow). Normal parafollicular cells (arrow) were present at the periphery of the thyroid follicles $(\mathrm{H} \& \mathrm{E}, \mathrm{X} 400$, scale bar=50 $\mu \mathrm{m})$.

Fig. (1B): A photomicrograph of the thyroid gland in the BPA treated group: The thyroid gland showed the follicles lined by vacuolated follicular cells (arrow) with darkly stained nuclei (curved arrow) and the colloid showed marked vacuolation (V). Also congested capillaries were present in the interfollicular spaces (zigzag arrow) (H\&E, X400, scale bar $=50 \mu \mathrm{m}$ ).

Fig. (1C) :A photomicrograph of the thyroid gland in the BPA treated group: The thyroid gland showed diminution of the size of some follicles (arrows) (H\&E, X400, scale bar $=50 \mu \mathrm{m}$ ).

Fig. (1D): A photomicrograph of the thyroid gland in the BPA treated group: The thyroid gland showing some thyroid follicles (F) present at the periphery of the section and coalescence of some thyroid follicles (arrow), also exfoliation of the epithelial cells (curved arrow) inside the colloid and disturbances of the basal lamina of some thyroid follicles (circular area) were observed (H\&E, X400, scale bar=50 m)

Fig. (1E): A photomicrograph of the thyroid gland in the recovery group: The thyroid gland showed most of thyroid follicles regained its normal architecture with disappearance of exfoliation of epithelial cells from their lumina. The follicles were filled with colloid (c) and lined with cubical follicular cells that had vesicular nuclei. The colloid of some follicles revealed some vacuoles (arrow head). Some congestion of blood capillaries (zigzag arrow) still noted between the follicles (H\&E, X400, scale bar $=50 \mu \mathrm{m})$. 


\section{Periodic Acid Schiff (PAS) staining:}

Periodic acid Schiff stained sections from thyroid gland of the control group showed strong positive PAS in the form of magenta color in the colloid and basement membrane of the thyroid follicles, also marginal colloidal vacuoles and positive reaction in the cytoplasm of epithelial follicular cells were noted (Fig. 2A). PAS stained thyroid sections of the BPA treated group showed marked decrease of colloidal PAS reaction in follicular lumina, even some thyroid follicles are devoid of colloid, also PAS reaction of basement membrane of the thyroid follicles was weak. A weak or even no PAS reaction in the cytoplasm of follicular cells was observed (Fig. 2B). PAS sections from thyroid gland of the recovery group showed obvious increase in the PAS reaction of the colloid and cytoplasm of the follicular cells compared to treated group but still less than the reaction in the control group. The colloid revealed different degrees of PAS reaction, also the basement membrane of some thyroid follicles showed increase in its PAS reaction when compared to treated group (Fig. 2C).

\section{Mallory's trichrome staining:}

Mallory's trichrome stained sections from thyroid gland of the control group revealed minimal collagen fibers around and in between the thyroid follicles (Fig. 3A) while in the BPA treated group showed marked increase of the blue color collagen fibers around and in between the thyroid follicles (Fig. 3B). Mallory's trichrome stained sections from thyroid gland of the recovery group showed minimal collagen fibers present around and in between the thyroid follicles but more than that in the control group (Fig. 3C).

\section{Bcl 2 immunohistochemistry staining:}

Bcl2 immunoexpression of thyroid gland of control group revealed strong reaction (dark brown) in the majority of follicular cells cytoplasm (Fig. $4 \mathrm{~A}$ ) while in the BPA treated group revealed faint brown color or negative $\mathrm{Bcl} 2$ immunoexpression in the cytoplasm of follicular cells (Fig. 4B). In the recovery group $\mathrm{Bcl} 2$ immunoexpression of thyroid gland revealed moderate reaction in most follicular cells (Fig. 4C).
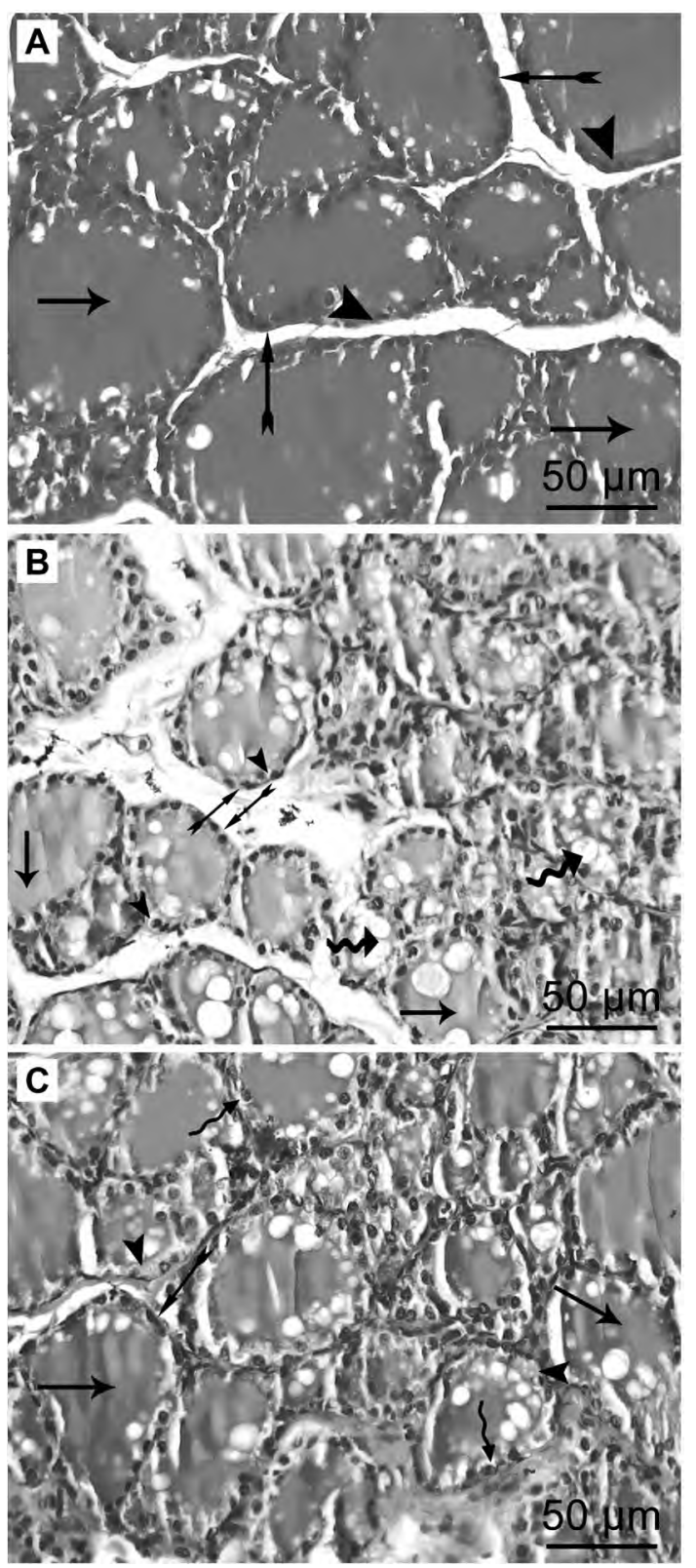

Fig. (2 A): A photomicrograph of the thyroid gland in the control group: The thyroid gland showed strong positive PAS reaction in the colloid (arrow) and in basement membrane (tailed arrow) of thyroid follicles, also in the cytoplasm of follicular cells arrow head) (PAS $\mathrm{X} 400$, scale bar $=50 \mu \mathrm{m}$ )

Fig. (2 B): A photomicrograph of the thyroid gland in the BPA treated group: The thyroid gland showed marked reduction of the colloidal PAS reaction in the follicular lumina (arrow) or even some thyroid follicles were devoid of colloid (zigzag arrow), also no PAS reaction in the cytoplasm of some follicular cells (arrow head) with weak PAS reaction of basement membrane of thyroid follicles (tailed arrow ) (PAS, X400, scale bar $=50 \mu \mathrm{m}$ ).

Fig. (2C): A photomicrograph of the thyroid gland in the recovery group: The thyroid gland showed obvious increase in the PAS colloida reaction (arrow) of some thyroid follicles compared to treated group. The cytoplasm of follicular cells showed moderate PAS reaction (arrow head), also vacuolated follicular cells is still present in some follicles (zigzag arrow) and PAS reaction of the basement membrane of some thyroid follicles increased (tailed arrow). (PAS, X400, scale bar $=50 \mu \mathrm{m})$. 

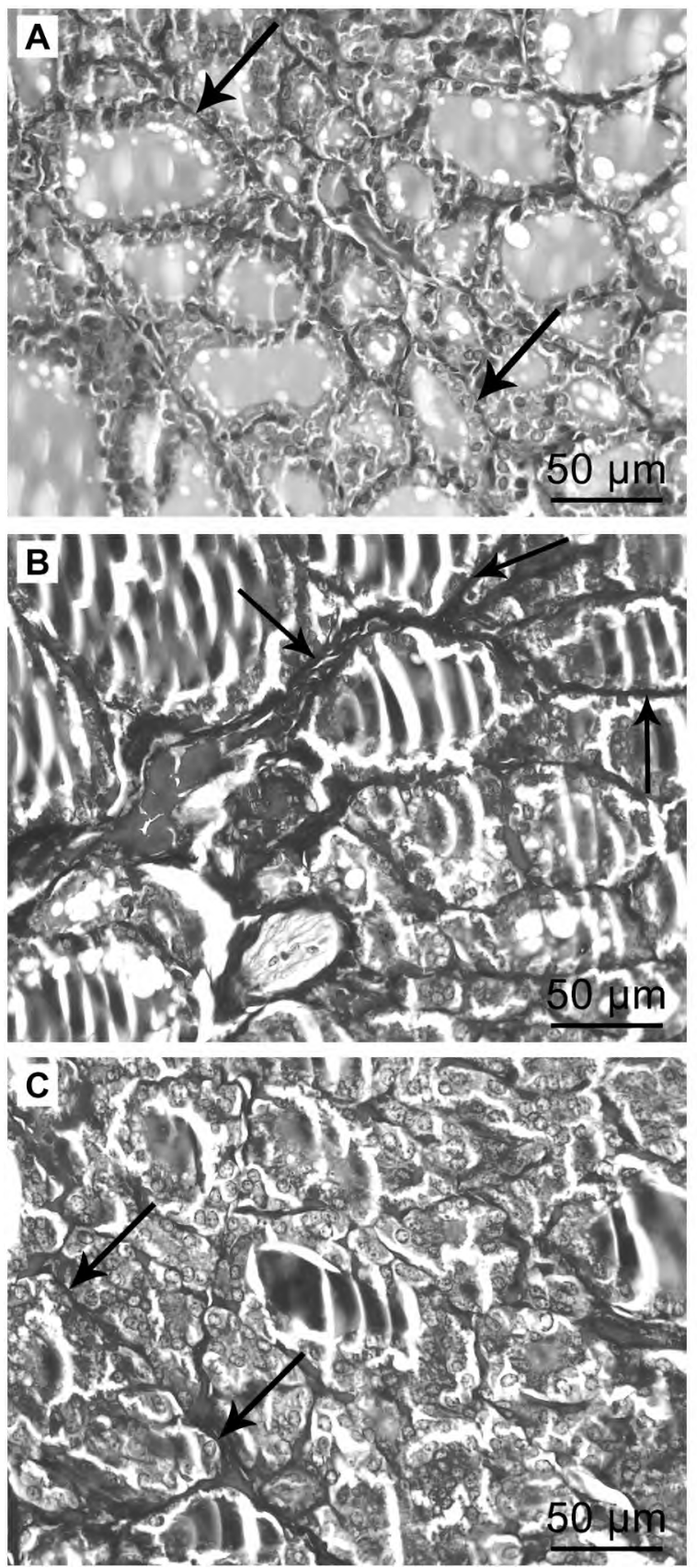

Fig. (3 A) : A photomicrograph of the thyroid gland in the control group: The thyroid gland showed minimal collagen fibers around thyroid follicles (arrow) (Mallory's trichrome, X400, scale bar=50 m)

Fig. (3 B): A photomicrograph of the thyroid gland in the BPA treated group: The thyroid gland showed marked increase of blue color collagen fibers around thyroid follicles (arrow) (Mallory's trichrome, X400, scale bar=50 m

Fig. (3 C): A photomicrograph of the thyroid gland in the recovery group: The thyroid gland showed minimal collagen fibers around thyroid follicles (arrow) (Mallory's trichrome, X400, scale bar= 50 m
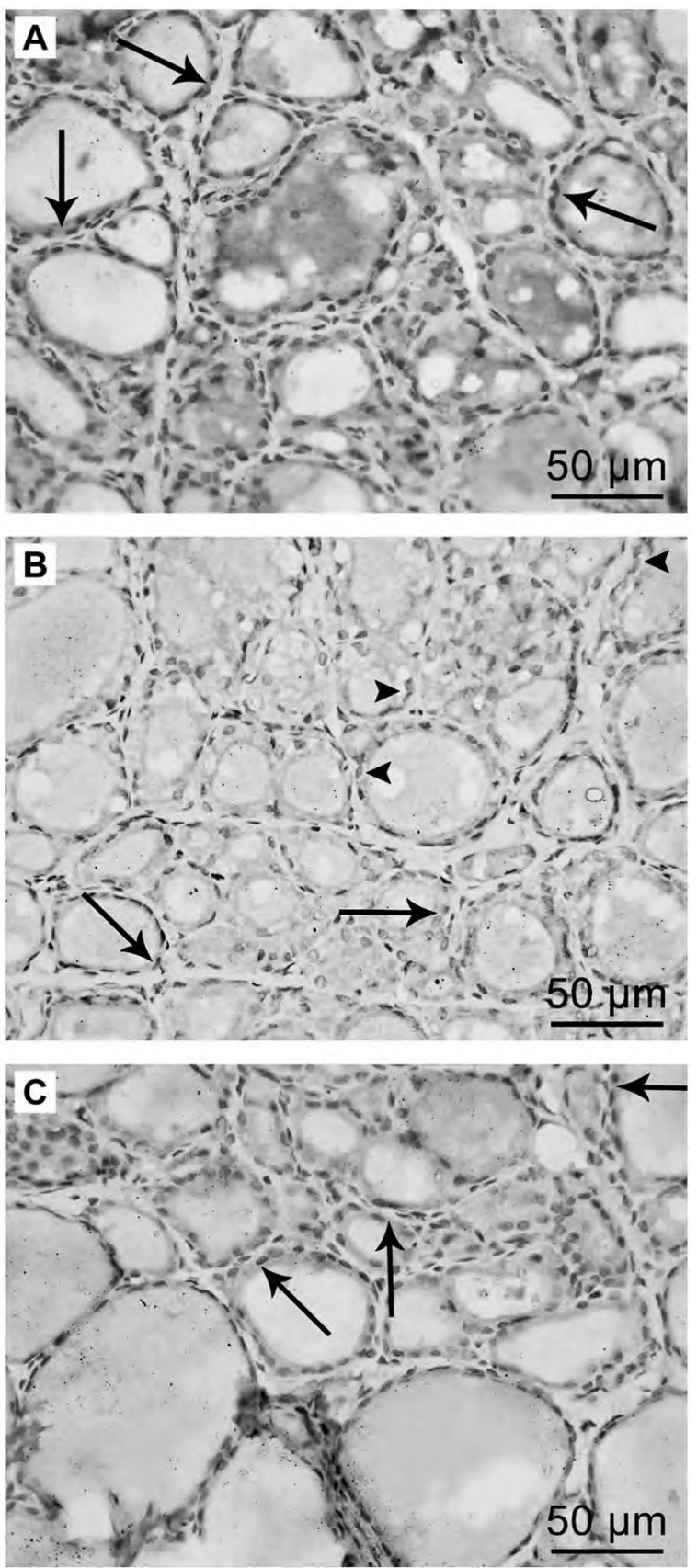

Fig. (4 A): A photomicrograph of the thyroid gland in the control group: The thyroid gland showed strong $\mathrm{Bcl} 2$ reaction (dark brown) in the cytoplasm of the majority of follicular cells (arrow) (Bcl2, $\mathrm{X} 400$, scale bar $=50 \mathrm{~m}$

Fig. (4 B): A photomicrograph of the thyroid gland in the BPA treated group: The thyroid gland showed faint brown reaction (arrow) or negative reaction (arrow head) in the cytoplasm of most follicular cells (Bcl2, X400, scale bar $=50$

Fig. (4 C): A photomicrograph of the thyroid gland in the recovery group: The thyroid gland showed moderate $\mathrm{Bcl} 2$ reaction in the cytoplasm of most follicular cells (arrow) (Bcl2, X400, scale bar= $50 \mathrm{ml}$ 


\section{Biochemical results:}

No statistical difference was found between the results of the negative control and positive control groups, so we used negative control group to be compared with other groups. In the BPA treated group, there was significant decrease of T3 and T4 with significant increase of TSH when compared with the control group $(p<0.001)$ while in the recovery group there were regressions in these results and showed significant difference in $\mathrm{T} 3, \mathrm{~T} 4$ and $\mathrm{TSH}$ in comparison to the treated group $(p<0.001)$. Also the results of the recovery group when compared to that of the control group showed significant difference in T3 and T4 levels $(p<0.001)$ while no significant difference regarding to $\mathrm{TSH}$ level $(p>0.05)$ (Tables 1,2).

\section{Morphometric results:}

Regarding to all morphometric parameters (EFD, FEH, area percentages of colloid, collagen fibers and $\mathrm{Bcl} 2$ immunoreaction) no statistical difference was found between the results of the negative control and positive control groups, so negative control group was used to be compared with other groups. Morphometric analysis of the results of BPA treated group when compared with the control group revealed that significant decrease of EFD, area percentages of colloid and $\mathrm{Bcl} 2$ immunoreaction $(p<0.001)$, also significant increase of FEH $(p<0.01)$ and area percentage of collagen fibers $(p<0.001)$. These parameters were improved partially in the recovery group (Tables 3,4 ).

Table (1): Showing Serum T3, T4 and TSH levels of different studied groups using ANOVA (analysis of variance) test.

\begin{tabular}{|c|c|c|c|c|}
\hline & $\begin{array}{l}\text { 1st Group } \\
\text { Mean } \pm \text { SD }\end{array}$ & $\begin{array}{l}\text { 2nd Group } \\
\text { Mean } \pm \text { SD }\end{array}$ & $\begin{array}{l}\text { 3rd Group } \\
\text { Mean } \pm \text { SD }\end{array}$ & $\begin{array}{c}p- \\
\text { value }\end{array}$ \\
\hline T3 (ng/ml) & $0.95 \pm 0.24$ & $0.50 \pm 0.08$ & $0.70 \pm 0.07$ & $0.000 * * *$ \\
\hline T4 ( g/ $/ 11)$ & $5.88 \pm 1.23$ & $3.18 \pm 0.30$ & $4.53 \pm 0.53$ & $0.000 * * *$ \\
\hline TSH ( Juml) & $0.56 \pm 0.10$ & $2.89 \pm 0.20$ & $0.67 \pm 0.15$ & $0.000 * * *$ \\
\hline
\end{tabular}

SD: Standard deviation. $* * *$ : Significant $(p<0.001)$.

Table (2): Showing comparison of T3, T4 and TSH levels between the studied groups by using Post Hoc test (LSD).

\begin{tabular}{lccc}
\hline & $\begin{array}{c}\text { 1st Group versus } \\
\text { 2nd Group }\end{array}$ & $\begin{array}{c}\text { 1st Group versus } \\
\text { 3rd Group }\end{array}$ & $\begin{array}{c}\text { 2nd Group versus } \\
\text { 3rd Group }\end{array}$ \\
\hline T3 & $(p$-value $)$ & $(p$-value $)$ & $(p$-value $)$ \\
& $0.000^{* * *}$ & $0.000 * * *$ & $0.000 * * *$ \\
T4 & $(p$-value $)$ & $(p$-value $)$ & $(p$-value $)$ \\
& $0.000^{* * *}$ & $0.000 * * *$ & $0.000 * * *$ \\
& & & \\
TSH & $(p$-value $)$ & $(p$-value $)$ & $(p$-value $)$ \\
& $0.000^{*} * *$ & $0.09 \mathrm{NS}$ & $0.000 * * *$ \\
\hline
\end{tabular}

NS: Non significant. $\quad * * *$ : Significant $(p<0.001)$.
Table (3): Morphometric analysis of follicular epithelial height (FEH), external follicular diameter (EFD), colloid area percentage, area percentage of collagen fibers around and in between the thyroid follicles, area percentage of immuno reaction of $\mathrm{Bcl} 2$ in different groups using ANOVA (analysis of variance) test.

\begin{tabular}{llllc}
\hline & $\begin{array}{c}\text { 1st Group } \\
\text { Mean } \pm \text { SD }\end{array}$ & $\begin{array}{c}\text { 2nd Group } \\
\text { Mean } \pm \text { SD }\end{array}$ & $\begin{array}{c}\text { 3rd Group } \\
\text { Mean } \pm \text { SD }\end{array}$ & $\begin{array}{c}p \text { - } \\
\text { value }\end{array}$ \\
\hline $\begin{array}{c}\text { Follicular } \\
\text { epithelial } \\
\text { height } \\
\text { (FEH) ( mm }\end{array}$ & $6.85 \pm 3.20$ & $10.33 \pm 3.19$ & $7.34 \pm 2.88$ & $0.003 * *$ \\
$\begin{array}{c}\text { External } \\
\text { follicular } \\
\text { diameter } \\
\text { (EFD) ( }\end{array}$ & $75.96 \pm 13.53$ & $54.60 \pm 10.57$ & $70.28 \pm 10.76$ & $0.000^{* * *}$ \\
$\begin{array}{c}\text { Colloid area } \\
\text { percentage }\end{array}$ & $62.31 \pm 4.83$ & $26.91 \pm 2.87$ & $58.32 \pm 3.57$ & $0.000^{* * *}$ \\
$\begin{array}{c}\text { Collagen area } \\
\text { percentage }\end{array}$ & $1.69 \pm 0.30$ & $8.53 \pm 2.02$ & $2.85 \pm 0.23$ & $0.000^{* * *}$ \\
$\begin{array}{c}\text { Area percentage } \\
\text { of Bcl 2 } \\
\text { reaction }\end{array}$ & $31.39 \pm 1.81$ & $13.33 \pm 0.67$ & $25.72 \pm 1.95$ & $0.000^{* * *}$ \\
\hline
\end{tabular}

SD : Standard deviation.

$*_{* *}$ : Significant $(0.01>p$-value $>0.001)$

*** : Significant $(p<0.001)$

Table (4): Showing comparison of follicular epithelial height (FEH), external follicular diameter (EFD), colloid area percentage, area percentage of collagen around and in between the thyroid follicles, area percentage of immuno reaction of $\mathrm{Bcl} 2$ in different groups by using Post Hoc test (LSD).

\begin{tabular}{|c|c|c|c|}
\hline & $\begin{array}{l}\text { 1st Group } \\
\text { versus } \\
\text { 2nd Group }\end{array}$ & $\begin{array}{l}\text { 1st Group } \\
\text { versus } \\
\text { 3rd Group }\end{array}$ & $\begin{array}{c}\text { 2nd Group } \\
\text { versus } \\
\text { 3rd Group }\end{array}$ \\
\hline FEH & $\begin{array}{l}(p \text {-value }) \\
0.003 * *\end{array}$ & $\begin{array}{l}(p \text {-value }) \\
0.687 \mathrm{NS}\end{array}$ & $\begin{array}{l}(p \text {-value }) \\
0.006^{* *}\end{array}$ \\
\hline EFD & $\begin{array}{l}(p \text {-value }) \\
0.000 * * *\end{array}$ & $\begin{array}{l}(p \text {-value }) \\
0.206 \mathrm{NS}\end{array}$ & $\begin{array}{l}(p \text {-value }) \\
0.000^{* * * *}\end{array}$ \\
\hline $\begin{array}{l}\text { Colloid area } \\
\text { percentage }\end{array}$ & $\begin{array}{l}(p \text {-value }) \\
0.000 * * *\end{array}$ & $\begin{array}{l}(p \text {-value }) \\
0.007 * *\end{array}$ & $\begin{array}{l}(p \text {-value }) \\
0.000 * * *\end{array}$ \\
\hline $\begin{array}{l}\text { Collagen area } \\
\text { percentage }\end{array}$ & $\begin{array}{l}(p \text {-value }) \\
0.000 * * *\end{array}$ & $\begin{array}{l}(p \text {-value }) \\
0.039^{*}\end{array}$ & $\begin{array}{l}(p \text {-value }) \\
0.000^{* * *} *\end{array}$ \\
\hline $\begin{array}{l}\text { Area percentage } \\
\text { of } \mathrm{Bcl} 2 \text { reaction }\end{array}$ & $\begin{array}{l}(p \text {-value }) \\
0.000 * * *\end{array}$ & $\begin{array}{l}(p \text {-value }) \\
0.000 * * *\end{array}$ & $\begin{array}{l}(p \text {-value }) \\
0.000^{* * *}\end{array}$ \\
\hline 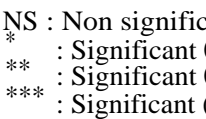 & $\begin{array}{l}p \text {-value }> \\
p \text {-value }> \\
01) .\end{array}$ & & \\
\hline
\end{tabular}

\section{Discussion}

In the past decades, there is production of more than ten billion pounds of BPA each year [22,23] Low doses of BPA have a very strong endocrinal disrupting effect [24-27], also exposure to BPA has associated with many diseases as diabetes, obesity, heart diseases and even cancer [28]. Affection of thyroid gland may result in behavioral and emotional changes throughout the day life, so researches that study the thyroid gland and its pathological disturbances have social and medical importance 
[29]. Thyroid hormones are essential for the normal growth and the physiological processes of mammals [30-32]. In the present study, BPA was adminstrated to the rats by using oral gavage that was preferred than mixing it with diet or drinking water due to the dose by this method is accurately adjusted [33] In this work, the rats in the BPA treated group showed significant reduction in the level of serum T3 \& T4 with significant increase in the level of TSH in comparison with the rats in control group. Sert et al., [34] revealed that the elevation of the level of serum TSH was due to active feedback loop when the levels of T3 \& T4 were reduced. Alkalby [17] reported that there was significant reduction of serum $\mathrm{T} 4$ with no significant increase of TSH in BPA treated rats. Zoeller [35] added that the mechanism of reduction of the level of circulating T4 without significant change in level of TSH is not obvious. In this work, H\&E stained section of thyroid gland of BPA treated rats revealed vacuolated colloid, decrease in the size of the thyroid follicles with appearance of micro follicles and these results were in accordance with the results of other studies [17]. BPA exposure induces oxidative stress [36] and increases the level of lipid peroxidation $[37,38]$. H\&E stained sections of thyroid gland of BPA treated group showed congestion and dilatation of the blood vessels as a result of oxidative stress and lipid peroxidation caused by BPA that might affect the walls of the blood vessels. Rajkovic et al., [39] revealed that the early response of stimulation of thyroid follicular cells by TSH is engulfment of the luminal colloid into the cytoplasm of thyrocytes and formation of a membrane bound the colloid droplets and these data could explain the reduction of the luminal colloid with weakness of its PAS reaction and appearance of cytoplasmic vacuolations of follicular cells of the thyroid gland in BPA treated group as a result of stimulation of these cells by increasing level of TSH in this group. Statistical analysis of the morphological results of BPA treated group showed a significant reduction in the diameter of thyroid follicles with significant increase in the height of the follicular epithelial cells that may be due to increasing of the proliferative state of thyroid follicular cells as a result of elevation of the serum level of TSH [40-42]. The morphology of thyroid follicles and production of thyroid hormones depend on serum TSH level and its increase results in follicular cells hyperplasia [39]. Geesin et al., [43] reported that there was a correlation between lipid peroxidation and collagen synthesis. In Mallory's trichrome stained sections of thyroid gland of BPA treated group showed thick collagen fibers around and in between thyroid follicles and this result might refer to increase the level of lipid peroxidation as a result of BPA exposure. Apoptosis in follicular cells of thyroid gland as a result of BPA exposure may be explained by induction of oxidative stress, also metabolism of BPA lead to generation of reactive oxygen species (ROS) that lead to DNA breaking [36]. BPA accumulates in the mitochondria and results in its dysfunction $[44,45]$. Bcl2 protein has an important role in achieving balance between inhibition and promotion of apoptosis [46,47]. Apoptosis of thyroid follicular cells in BPA treated rats was demonstrated histologically by vacuolated cytoplasm and immunohistochemically by a faint Bcl 2 immune expression that was confirmed statistically by significant decrease in its area percentage when compared with control group.

In the 3 rd group, partial recovery of thyroid gland after stoppage of exposure to BPA was demonstrated as most of thyroid follicles regained its normal appearance with little collagen fibers around and in between these follicles, moderate $\mathrm{Bcl} 2$ reaction of follicular cells and increased PAS reaction of colloid of thyroid follicles but still less than that of the control group. Also, this recovery was demonstrated biochemically by elevation of the serum level of T3 \& T4 with reduction of TSH level when compared with the treated group. Some researchers studied the effect of BPA on different organs as testis and they noticed that the testis showed partial recovery after stoppage of BPA exposure [15]. Moreover, other researchers revealed the capability of recovery of thyroid gland after stoppage of the exposure to different harmful factors as low frequency electromagnetic fields [48].

Conclusion: Exposure to BPA could lead to structural and hormonal disturbances of thyroid gland and these disturbances are incompletely reversible after stoppage of BPA administration.

Acknowledgement: The authors are grateful to (ZSMRC) for allowing and supporting the experimental study in their laboratories.

Conflicts of interest: There are no conflicts of interest.

\section{References}

1- LATONNELLE K., LE MENN. F. and BENNETAUPELISSERO C.: In vitro estrogenic effects of phytoestrogens in rainbow trout and Siberian sturgeon. Ecotoxicology, 9 (1-2): 115-125, 2000.

2- MORIYAMA K., TAGAMI T., AKAMIZU T., USUI T., SAIJO M., KANAMOTO N., HATAYA Y., SHIMATSU A., KUZUYA H. and NAKAO K.: Thyroid hormone 
action is disrupted by bisphenol $\mathrm{A}$ as an antagonist. The Journal of Clinical Endocrinology \& Metabolism, 87 (11): 5185-5190, 2002.

3- MASSART F., PARRINO R., SEPPIA P., FEDERICO G. and SAGGESE G.: How do environmental estrogen disruptors induce precocious puberty ? Minerva Pediatrica, 58 (3): 247-254, 2006

4- KUROSAWA T., HIROI H., TSUTSUMI O., ISHIKAWA T., OSUGA Y. FUJIWARA T., INOUE S., MURAMATSU M., MOMOEDA M. and TAKETANI Y.: The activity of bisphenol A depends on both the estrogen receptor subtype and the cell type. Endocrine Journal, 49 (4): 465-471, 2002.

5- SHELBY M.D.: NTP-CERHR monograph on the potential human reproductive and developmental effects of bisphenol A. NTP CERHR MON, (22): v, vii-ix: 1-64, 2008.

6- AHMED W.M.S., MOSELHY W.A. and NABIL T.M.: Bisphenol A Toxicity in Adult Male Rats: Hematological, Biochemical and Histopathological Approach. Global Veterinaria, 14 (2): 228-238, 2015.

7- STAPLES C.A., DOME P.B., KLECKA G.M., O'BLOCK S.T. and HARRIS L.R.: A review of the environmental fate, effects and exposures of bisphenol A. Chemosphere, 36 (10): 2149-2173, 1998.

8- TAYLOR H.S.: Endocrine disruptors affect developmental programming of HOX gene expression. Fertil. Steril., 89 (2): e57-e58, 2008.

9- MICHALOWICZ J.: Bisphenol A-Sources, toxicity and biotransformation. Environmental Toxicology and Pharmacology, 37 (2): 738-758, 2014.

10- RUBIN B.S.: Bisphenol A: An endocrine disruptor with widespread exposure and multiple effects. J. Steroid. Biochem. Mol. Biol., 127 (1-2): 27-34, 2011.

11- HAN D.H., KIM M.J., JUN E.J. and KIM J.B.: Salivary Bisphenol-A Levels due to Dental Sealant/Resin: A CaseControl Study in Korean Children. J. Korean Med. Sci., 27 (9): 1098-1104, 2012.

12- PORTERFIELD S.P.: Thyroidal dysfunction and environmental chemicals-potential impact on brain development Environmental Health Perspectives, 108 (Suppl 3): 433$438,2000$.

13-KASSAB A.A. and EL-AASR M.: Effect of Avocado pulp extract on chlorpyrifos-induced thyroid gland injury in rats: A histological and morphometric study. Egyptian Journal of Histology, 41 (1): 83-92, 2018.

14- RICHTER C.A., BIRNBAUM L.S., FARABOLLINI F., et al.: In Vivo Effects of Bisphenol A in Laboratory Rodent Studies. Reprod. Toxicol., 24 (2): 199-224, 2007.

15- MOHAMED D.A. and ARAFA M.H.: Testicular toxic changes induced by bisphenol $\mathrm{A}$ in adult albino rats: $\mathrm{A}$ histological, biochemical, and immunohistochemical study. Egyptian Journal of Histology, 36 (1): 233-245, 2013.

16- HEGAZY, A.A., OMAR A.M.A., HUSSEIN Y., ABDUL RAHMAN, M.M. and EL-BESTAWY E.M.: Effect of bisphenol A on corpus epididymis and chromosomal pattern of adult rats. Z.U.M.J., 23 (3): 171-181, 2017.

17-ALKALBY J.M.A.: Effect of bisphenol A on thyroid, liver and testicular functions in adult male rats. Bas. J. Vet. Res., 14 (1): 187-206, 2015.
18- BANCROFT J.D. and LAYTON C.: The Hematoxylin and Eosin. Ch:10 and Connective and mesenchymal tissues with their stains, Ch : 11 In: Suvarna S.K., Layton C., Bancroft J.D. editors. Theory and Practice of histological techniques, ${ }^{7 \text { th }}$ ed., Churchill Livingstone, London, pp. 173-214, 2012.

19- BANCROFT J.D.: Histochemical techniques, 2 nd ed., Butterworth-Heinemann, London, pp. 68-102, 2013.

20- KIERNAN J.: Histological and histochemical methods: Theory and practice. ${ }^{\text {ed. }}$., Butterworth-Heinemann, Oxford, pp. 320-390, 2000.

21- KURIYAMA S.N., WANNER A., FIDALGO-NETO A.A., TALSNESS C.E., KOERNER W. and CHAHOUD I.: Developmental exposure to low-dose PBDE-99: Tissue distribution and thyroid hormone levels. Toxicology, 242 (1-3): 80-90, 2007.

22- VANDENBERG L.N., CHAHOUD I., HEINDEL J.J., PADMANABHAN V., PAUMGARTTEN F.J. and SCHOENFELDER G.: Urinary, circulating, and tissue biomonitoring studies indicate widespread exposure to bisphenol A. Environmental. Health Perspectives, 118 (8): 1055-1070, 2010.

23- VOM SAAL F.S., NAGEL S.C., COE B.L., ANGLE B.M. and TAYLOR J.A.: The estrogenic endocrine disrupting chemical bisphenol A (BPA) and obesity. Mol. Cell. Endocrinol., 354 (1-2): 74-84, 2012.

24- ROCHESTER J.R.: Bisphenol A and human health: A review of the literature. Reproductive Toxicology, 42: 132-155, 2013.

25- MILEVA G., BAKER S.L., KONKLE A. and BIELAJEW C.: Bisphenol-A: Epigenetic reprogramming and effects on reproduction and behavior. Int. J. Environ. Res. Public. Health, 11 (7): 7537-7561, 2014.

26- REZG R., EL-FAZAA S., GHARBI N. and MORNAGUI B.: Bisphenol A and human chronic diseases: Current evidences, possible mechanisms, and future perspectives. Environment International, 64: 83-90, 2014.

27- MATHIEU-DENONCOURT J., WALLACE S.J., DE SOLLA S.R. and LANGLOIS V.S.: Plasticizer endocrine disruption: Highlighting developmental and reproductive effects in mammals and non-mammalian aquatic species. Gen. Comp. Endocrinol., 219: 74-88, 2015.

28- SEACHRIST D.D., BONK K.W, HO S.M., PRINS G.S., SOTO A.M. and KERI R.A.: A review of the carcinogenic potential of bisphenol A. Reproductive Toxicology, 59: 167-182, 2016.

29- RAJAB N.M.A., UKROPINA M. and CAKIC-MILOSEVIC M.: Histological and ultrastructural alterations of rat thyroid gland after short-term treatment with high doses of thyroid hormones. Saudi Journal of Biological Sciences, 24 (6): 1117-1125, 2017.

30- SILVA J.E.: Thyroid hormone control of thermogenesis and energy balance. Thyroid, 5 (6): 481-492, 1995.

31- CAVALIERI R.R.: Iodine metabolism and thyroid physiology: Current concepts. Thyroid, 7 (2): 177-181, 1997.

32- TUZMEN N., CANDAN N., KAYA E. and DEMIRYAS N.: Biochemical effects of chlorpyrifos and deltamethrin on altered antioxidative defense mechanisms and lipid peroxidation in rat liver. Cell Biochemistry \& Function, 26 (1): 119-124, 2008. 
33- SHEHATA M.R., MOHAMED D.A., EL-MELIGY M.M.S. and BASTWROUS A.E.: The effect of maternal hypothyroidism on the postnatal development of the pituitary-thyroid axis in albino rats: A histological, morphometric and immunohistochemical study. Journal of Current Medical Research and Practice, 2 (1): 79-97, 2017.

34- SERT C., CELIK M.S., AKDAĞ Z., KETANI M.A. and NERGIZ Y.: The radioprotective effect of vitamins $C, E$ and vitamin E+Glutathione on the small intestine and the thyroid gland in rats irradiated with X-rays. Trukish Jounal of Medical Sciences, 30 (5): 417-425, 2000.

35- ZOELLER T.R.: Environmental chemicals targeting thyroid. Hormones, (Athens, Greece), 9 (1): 28-40, 2010.

36- GASSMAN N.R.: Induction of oxidative stress by bisphenol A and its pleiotropic effects. Environmental Molecular Mutagenesis, 58 (2): 60-71, 2017.

37- WATKINS D.J., FERGUSON K.K., DEL TORO L.V.A., ALSHAWABKEH A.N., CORDERO J.F. and MEEKER J.D.: Associations between urinary phenol and paraben concentrations and markers of oxidative stress and inflammation among pregnant women in Puerto Rico. Int. J. Hyg. Environ. Health, 218 (2): 212-219, 2015.

38- ZHANG T., XUE J., GAO C.Z., QIU R.L., LI Y.X., LI $\mathrm{X}$. and KANNAN K. : Urinary Concentrations of Bisphenols and Their Association with Biomarkers of Oxidative Stress in People Living Near E-Waste Recycling Facilities in China. Environ., Sci Technol., 50 (7): 4045-4053, 2016.

39- RAJKOVIC V., MATAVULJ M. and JOHANSSON O.: Light and electron microscopic study of the thyroid gland in rats exposed to power-frequency electromagnetic fields. J. Exp. Biol., 209: 3322-3328, 2006.

40- SERAKIDES R., NUNES V.A., SANTOS R.L., CASSALI G.D. and NETO P.C.: Histomorphometry and quantification of nucleolar organizer regions in bovine thyroid containing methylthiouracil residues. Veterinary Pathology, 36 (6): 574-582, 1999.
41- FERREIRA E., SILVA A.E., SERAKIDES R., GOMES A.E.S. and CASSALI G.D.: Model of induction of thyroid dysfunctions in adult female mice. Arq. Bras. Med. Vet. Zootec., 59 (5): 1245-1249,2007.

42- MOSTAGHNI K., BADIEI K., KHODAKARAM-TAFTI A. and MAAFI A.B.: Pathological and biochemical studies of experimental hypothyroidism in sheep.Veterinarski Arhiv, 78 (3): 209-216, 2008.

43- GEESIN J.C., HENDRICKS L.J., FALKENSTEIN P.A., GORDON J.S. and BERG R.A.: Regulation of collagen synthesis by ascorbic acid: Characterization of the role of ascorbate-stimulated lipid peroxidation. Archives of Biochemistry and Biophysics, 290 (1): 127-132, 1991.

44- OOE H., TAIRA T., IGUCHI-ARIGA S.M. and ARIGA H.: Induction of reactive oxygen species by bisphenol A and abrogation of bisphenol A-induced cell injury by DJ1. Toxicological Sciences, 88 (1): 114-126, 2005.

45- CHEPELEV N.L., ENIKANOLAIYE M.I., CHEPELEV L.L., ALMOHAISEN A., CHEN Q., SCOGGAN K.A. and WILLMORE W.G.: Bisphenol A activates the Nrf1/2antioxidant response element pathway in HEK 293 cells. Chem. Res. Toxicol., 26 (3): 498-506, 2013.

46- SUZUKI A., MATSUZAWA A. and IGUCHI T.: Down regulation of Bcl-2 is the first step on Fas-mediated apoptosis of male reproductive tract. Oncogene, 13 (1): 31-37, 1996.

47- CHEN S., FAZLE AKBAR S.M., ZHEN Z., LUO Y., DENG L., HUANG H. and LI W.: Analysis of the expression of Fas, FasL and Bcl-2 in the pathogenesis of autoimmune thyroid disorders. Cell. Mol. Immunol., 1 (3): 224-228, 2004.

48- MOHAMED D.A. and ELNEGRIS H.M. : Histological Study of Thyroid Gland after Experimental Exposure to Low Frequency Electromagnetic Fields in Adult Male Albino Rat and Possible Protective Role of Vitamin E. J. Cytol. Histol., 6: 374, doi:10.4172/2157-7099.1000374, 2015.

\section{مخاطر البسفينول-أ على الغدة الدرقية فى ذكور الجرذان البيضاء البالغة وإمكانية الإستشفاء بعد إنسحابه فيله}



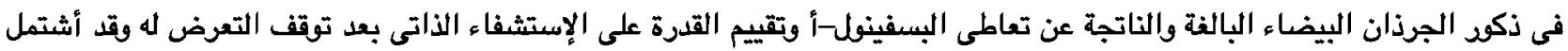

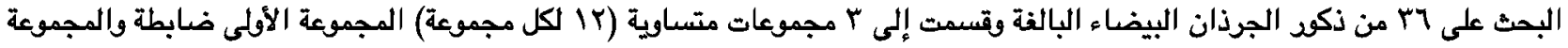



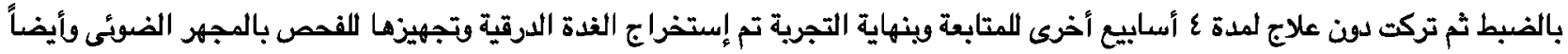

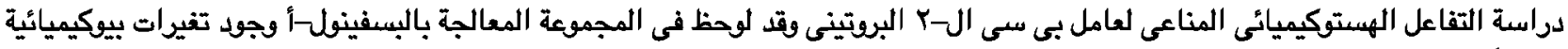

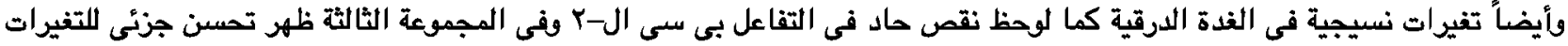

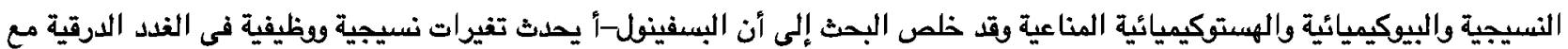

